\begin{tabular}{|c|c|}
\hline & $\begin{array}{l}\text { International Journal of Trend in Scientific } \\
\text { Research and Development (IJTSRD) }\end{array}$ \\
\hline 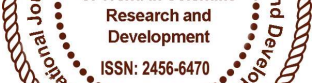 & International Open Access Journal \\
\hline 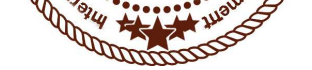 & ISSN No: 2456 - 6470 | www.ijtsrd.com | Volume - 2 | Issue - 2 \\
\hline
\end{tabular}

\title{
Determination of Physicochemical Parameters and Heavy Metal Levels in Some Well Water of Gwaram Town Jigawa, Northwest Nigeria
}

\author{
B. B, Yusif \\ Nigerian Institute of Leather \\ and Science Technology, Kano \\ Extension Center, Zawaciki \\ Kano, Nigeria \\ A. Anteyi \\ Nigerian Institute of Leather \\ and Science Technology, Kano \\ Extension Center, Zawaciki \\ Kano, Nigeria \\ K. A, Bichi \\ Nigerian Institute of Leather \\ and Science Technology, Kano \\ Extension Center, Zawaciki \\ Kano, Nigeria

\section{A. B, Mu'azu} \\ Department of Science Laboratory Technology, \\ Mai Idris Alooma Polytechnic Geidam, \\ Yobe State, Nigeria

\section{Chutiyami} \\ College of Nursing and Midwifery Damaturu, \\ Yobe State, Nigeria
}

\section{ABSTRACT}

The study was aimed at determining physicochemical parameters of water including temperature, $\mathrm{pH}$, electrical conductivity (EC) and total dissolved solid (TDS)as well as heavy metals $(\mathrm{Cu}, \mathrm{Cr}, \mathrm{Fe}, \mathrm{Mn}, \mathrm{Pb}$, and $\mathrm{Zn}$ )collected from well waters in Gwaram town, Jigawa state of Nigeria. Eight different wards (Auyakawa, Bare-Bari, Fada, Gagaryaga, Kawari, Kuka, Kurna and Wurya) were selected and their water samples were collected based on their closeness to pollution sources. Analysis of the physicochemical parameters were determined using universal handheld $\mathrm{pH}$ meter and TDS meter, while heavy metals were determined by atomic absorption spectrometry. The results showed that the $\mathrm{pH}$ of all the samples were within the WHO limit. On the other hand, the TDS for all the samples are above the WHO upper limit and the EC of Bare-bari, Fada, Kuka and Kurna are below the WHO upper limit. Gagaryaga has the same as WHO upper limit while Auyakawa, Kawari and Wurya have above the WHO upper limit. Heavy metals in the samples are within the permissible limits when compared with WHO upper limit except Cuand Fe that are higher in Auyakawa, Kawari and Wurya. It was thus concluded that the major source of drinking water in Gwaram has the potential to cause a number of preventable public health problems. It is hence recommended that the state government (Jigawa) as well as public health non-governmental organizations should put more effort towards providing a portable drinking water to neglected areas like Gwaram.

Keywords: Physicochemical, Heavy metals, Well water

\subsection{INTRODUCTION}

Water is a precious natural resource that exists on earth, thus the current concern to quality of environment focused on water because of its significant role to human and the ecosystem [1]. Availability of sufficient drinking water continues to be a major problem in the public health, because of its importance to the environment, which is also essential for the survival of all living things including plants and animals, hence the need to maintain it clean and unpolluted [2,3]. Water covers $71 \%$ of the earth's surface and makes up $65 \%$ of our body [3]. Its sources are usually polluted by chemicals and microbial contaminants which leads to waterborne infections and diseases [3]. Therefore, guidelines and 
legislation has stated that water suitable for drinking should contain some parameters including microorganisms in low amounts such that the risk for acquiring waterborne infections is below an acceptable limit [4]. In the industrialized nations, high standards of drinking water are set for its quality and safety [5,6]. Rapid urbanization of rural areas, industrialization and population growth have been the major causes of stress on the environment leading to serious problems to human being and climatic changes [7].

Nigeria being one of the most populous and industrialized nations in Africa is faced with a number of water-borne related diseases. Gwaram town which is the headquarter of Gwaram local government in Jigawa state of Nigeria is one of the semi urban settlements with estimated population of over 15,000 people [8]. This population is growing daily which leads to the increase in the need of portable drinking water, which is vital for the health of the populace. This study was aimed at determining the physicochemical parameters and heavy metal levels in selected hand dug well waters in Gwaram, which is the major source of drinking water for over $60 \%$ of its population.

\subsection{METHODOLOGY}

\subsection{Sampling Sites}

Water samples from handdug wellsin eight different wards (Auyakawa, Bare-Bari, Fada, Gagaryaga, Kawari, Kuka, Kurna and Wurya) were collected based on their closeness to pollution sources. The major pollution sources considered are; dumpsites, drainage, public convenience and automobile exhaust, the wells are the source of water for domestic and commercial use of the people of Gwaram town as majority of them are located within the domestic areas.

Table 1: Mean values of physicochemical parameters of well water and comparison with WHO guideline.

\begin{tabular}{|c|c|c|c|c|c|c|c|c|c|}
\hline PARAMETERS & AUYAKAWA & BARE-BARI & FADA & GAGARYAGA & KAWARI & KUKA & KURNA & WURYA & 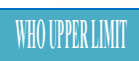 \\
\hline TEMP ${ }^{0} \mathrm{C}$ & $30.4 \pm 0.2$ & $30.1 \pm 0.7$ & $29.8 \pm 1.0$ & $31.1 \pm 0.6$ & $30.0 \pm 0.2$ & $30.5 \pm 0.4$ & $30.4 \pm 1.1$ & $30.2 \pm 0.8$ & - \\
\hline $\mathbf{H}$ & $6.9 \pm 0.4$ & $7.2 \pm 0.8$ & $7.6 \pm 0.3$ & $7.1 \pm 0.5$ & $6.8 \pm 0.9$ & $6.7 \pm 1.4$ & $7.2 \pm 0.5$ & $7.5 \pm 0.4$ & $6.5-8.5$ \\
\hline TDS (mg/L) & $1050 \pm 3.2$ & $750 \pm 2.4$ & $725 \pm 2.1$ & $700 \pm 1.8$ & $950 \pm 4.1$ & $780 \pm 2.8$ & $690 \pm 1.3$ & $865 \pm 1.5$ & $\begin{array}{lll}5 & 0 & 0\end{array}$ \\
\hline $\mathrm{EC}(\mu \mathrm{s} / \mathrm{cm}$ & $900 \pm 0.9$ & $340 \pm 1.0$ & $320 \pm 1.5$ & $400 \pm 0.6$ & $750 \pm 1.5$ & $300 \pm 1.2$ & $250 \pm 1.0$ & $600 \pm 1.4$ & 400 \\
\hline
\end{tabular}

Values are presented as mean \pm SEM, $\mathrm{n}=3$, SEM: Standard Error of Mean 


\subsection{Heavy Metals}

The analysis of the samples showed that the concentrations of $\mathrm{Cu}$ in all the samples are below the WHO upper limits except for samples collected from Auyakawa, Kawari and Wurya. Cr was only detected in Kuka, Kurna and Wurya. Fe was detected in all the samples except for Bare-bari, and the samples from Auyakawa, Kawariand wurya have concentrations above the WHO upper limit. Mn was not detected in Fada and Gagaryaga and the concentrations in the other locations were below the WHO upper limit. Pb was not detected in the all the samples analyzed. Zn concentrations in all the samples are below the WHO upper limit.

\section{Table 2: Mean values heavy metalsof well water and comparison with WHO guideline.}

\begin{tabular}{|c|c|c|c|c|c|c|c|c|c|c|}
\hline PAR: & & AUYAKAWA & BARE-BARI & FA DA & GAGARYAGA & KAWARI & KUKA & KURNA & WURYA & 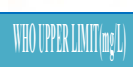 \\
\hline $\mathbf{C}$ & $\mathbf{u}$ & $3.134 \pm 0.2$ & $1.230 \pm 0.3$ & $0.951 \pm 0.5$ & $1.032 \pm 0.3$ & $2.951 \pm 0.5$ & $1.034 \pm 0.4$ & $0.802 \pm 0.5$ & $3.032 \pm 0.4$ & .000 \\
\hline $\mathbf{C}$ & $\mathbf{r}$ & D & $\mathrm{N}$ & $\mathrm{N}$ & $\mathrm{N}$ & $\mathrm{D}$ & $0.026 \pm 0.1$ & \pm 0.1 & $0.038 \pm 0.2$ & 0.050 \\
\hline $\mathbf{F}$ & e & $1.920 \pm 0.7$ & $\mathrm{~N}$ & $0.007 \pm 0.3$ & $0.003 \pm 0.0$ & $1.820 \pm 0.2$ & $0.090 \pm 0.1$ & $0.160 \pm 0.3$ & $1.220 \pm 0.6$ & 0.200 \\
\hline $\mathbf{M}$ & $\mathbf{n}$ & $0.008 \pm 0.1$ & $0.030 \pm 0.1$ & $\mathrm{~N} \quad \mathrm{D}$ & $\mathrm{N}$ & $0.020 \pm 0.1$ & $0.010 \pm 0.2$ & $0.020 \pm 0.1$ & $0.030 \pm 0.3$ & 0.050 \\
\hline $\mathbf{P}$ & $\mathbf{b}$ & $\mathrm{D}$ & $\mathrm{N}$ & $\mathrm{N}$ & $\mathrm{N} C \mathrm{C} \| \mathrm{D}$ & $\mathrm{N}, \mathrm{D}$ & $\mathrm{N}$ & $\mathrm{N}$ & $\mathrm{N}$ & 0.050 \\
\hline $\mathbf{Z}$ & $\mathbf{n}$ & $3.513 \pm 1.0$ & $2.113 \pm .4$ & $2.124 \pm 0.3$ & $1.761 \pm 0.4$ & $1.112 \pm 0.2$ & $1.002 \pm 0.1$ & $2.471 \pm 0.6$ & $3.231 \pm 0.7$ & 5.000 \\
\hline
\end{tabular}

Values are presented as mean \pm SEM, $n=3$, ND: Not Detected, SEM: Standard Error of Mean

\subsection{DISCUSSION}

Temperature is an essential parameters in water due to the significant impact it has on the growth and activity of ecological life, as well as great effects on the oxygen solubility in water [12]. The temperature of hand dug well water samples have been found to be in the range of $29{ }^{\circ} \mathrm{C}-31{ }^{\mathrm{O}} \mathrm{C}$. The $\mathrm{pH}$ value is very important determinant of water quality that indicates the presence of alkali or acid in water samples. It also affects chemical reactions such as metal toxicity and solubility $[12,13]$. The $\mathrm{pH}$ of the samples analyzed in this study was within the permissible limit of the World Health Organization. Electrical conductivity which is a measure of water's ability to conduct an electric current is also related to the level of dissolved minerals in the water [14]. Conductivity is a good and rapid method to measure the total dissolved ions, it is related directly to the total solids found in the water sample [15]. Water samples collected from Auyakawa, Kawari and Wurya shows $900 \mu \mathrm{s} / \mathrm{cm}$, $750 \mu \mathrm{s} / \mathrm{cm}$ and $600 \mu \mathrm{s} / \mathrm{cm}$ respectively, which is above the WHO standard limit of $400 \mu \mathrm{s} / \mathrm{cm}$. This may be related to the high level of total dissolved solids found in all the three locations which is above the WHO upper limit and subsequently may be due impurities in the water which can render the water unfit for drinking.

Lead is one of the most harmful heavy metals because of its common toxicity that is very harmful even in

small concentration [16]. It enters the human body through many routes, and removed mostly in the urine. High concentration in the body can cause permanent damage to the kidneys, central nervous system, brain, or even death [17]. Lead was not detected in all the water samples collected.

Iron occurs mainly in water as ferric or ferrous state [18]. It is one of the essential trace elements found in significant concentration in drinking water because of its abundance [19]. The deficiency of iron causes disease such as anemia, while at high concentration it is associated with liver disease called haemosiderosis [19]. Concentrations of iron in some of the samples are within WHO limits except for Auyakawa, Kawari and Wurya with $1.92 \mathrm{mg} / \mathrm{L}, 1.81 \mathrm{mg} / \mathrm{L}$ and 1.22 $\mathrm{mg} /$ Lrespectively. High concentration of iron in water imparts taste and promotes growth of iron bacteria that accelerate rusting process of ferrous metals that are exposed to water [20].

Zinc is an important trace element that plays a vital role in the physiological, biochemical process of organisms and protein synthesis [22]. Nonetheless, it is toxic to organisms at high concentrations [22]. The concentrations in the samples were within the WHO upper limit. Water contaminated with high concentration of copper can cause chronic anemia, impart bitter taste to water and promotes corrosion of galvanized iron and steel fittings[23, 24]. The 
concentrations of copper detected in the samples collected in Auyakawa, kawariandWurya were above the permissible limits of the WHO.

Chromium is an essential micronutrient for plants and animals. It is considered as a biological pollutant, because it is toxic at high concentration especially when in the hexavalent form. Sub chronic and chronic exposure to chromic acid can causeulceration of the skin and dermatitis, while long-term exposure can lead to liver, kidney, circulatory and nerve tissue damages. Chromium often accumulates in aquatic life, which adds to the danger of eating fish that may have been exposed to high level of chromium [17, 18]. Chromium was detected in only Kuka, Kurna and Wurya, with concentrations lower than that of WHO upper limit. The concentrations of manganese in all the samples were below WHO upper limit.Excess manganese can interfere with absorption of dietary iron, which can result in iron deficiency such as anemia. It also increases bacterial growth, and excess manganese intake can lead to hypertension in people above 40 years [25].

\subsection{CONCLUSION}

The result showed high concentration of some parameters such as electrical conductivity and total dissolved solutes. These may be due to the presence of high concentration of heavy metals in Auyakawa, Kawari and Wurya.The concentrations of some heavy metals in the samples arewithin the permissible limits when compared with WHO upper limit except cupper and iron that are higher in Auyakawa, Kawari and Wurya. This is an indication of pollution hazards in these areas which, in turn, have implications on the health to the people of the area. It is thus recommended that the state government (Jigawa) as well as public health non-governmental organizations should put more effort towards providing a portable drinking water to neglected areas like Gwaram.

\section{REFRENCES}

1. Mahananda, M.R., Mohanty, B.P., and Behera, N.R. (2010). "Physicochemical analysis of surface and ground water of Bargarh district, Orissa, India".International Journal of Research and Reviews in Applied Sciences, 2(3) pp.284-295

2. Postel, S. (1997). Last oasis: facing water security. New York, Norton, p 17-191.
3. USEPA (1991). Is your drinking water safe? Office of water (WH-550), EPA 570/9-91-005, Washington DC.

4. Zan F., Huo S., Xi B., Li Q., Liao H. and Zhang, J. (2011). Phosphorus distribution in the sediments of a shallow eutrophic lake, Lake Chaohu, China. Environmental Earth Science, 62: 1643-1653

5. Bishnoi, M and Arora, S. (2007). Potable ground water quality in some villages of Haryana, India: focus on fluoride. Journal of Environmental Biology, 28(2): 291-294.

6. Akoto, O and Adiyiah, J. (2007). Chemical analysis of drinking water from some communities in the brongahafo region. International Journal of Environmental Science and Technology, 4(2):211-214.

7. Bay, S. M., Zeng, E. Y., Lorenson, T. D., Tran, K. and Alexander, C. (2003). Temporal and spatial distributions of contaminants in sediments of Santa Monica Bay, California. Marine Environmental Research, 56 (1-2), 255 - 276.

8. National Population Commission. 2006 Nigerian National Population Census. NPC Abuja Nigeria.

9. APHA standard methods for examination of water and cwaste water, American Public health Association, Washington D.C.( 1998).

10. NEERI (1986). Manual on water and waste water analysis, National Environmental Engineering Research Institute Publication, Nagpur-P-340.

11. AOAC (1998). American Organisation of Analytical Chemistry; A guide to Chemical Analysis, 7.

12. Kataria H.C, Gupta M, Kumar M, Kushwaha S, Kashyap S, Trivedi S, Bhadoriya R. and Bandewar K.(2011) Study of Physico-chemical Parameters of Drinking Water of Bhopal city with Reference to Health Impacts. Current World Environment 6(1);95-99

13. Fakayode S. O., (2005). Impact of industrial effluents on water quality of the receiving Alaro River in Ibadan, Nigeria, Ajeam-Ragee, 10, 1-13.

14. Pandey, J., Shubhashish, K and Pandey, R. (2010). Heavy metal contamination of Ganga river at Varanasi in relation to atmospheric deposition. Tropical Ecology, 51(2):365-373.

15. Singh M. R, Asha, G. and Beeteswari, K.H. (2010). Physico-chemical Properties of Water 
Samples from Manipur River System, India. Journal of Applied Sciences and Environmental Management Vol. 14 (4) 85 - 89.

16. Gregoriadou, A., Delidou, K., Dermosonoglou, D., Tsoumparis, P., Edipidi, C. and Katsougiannopoulos, B. (2001). Heavy metals in drinking water in Thessaloniki area, Greece. 7th International Conference on Environmental Science and Technology., Greece.

17. Salem, H.M., Eweida, E.A. and Farag, A. (2000). Heavy metals in drinking water and their environmental impact on human health. In ICEHM 2000; Cairo University: Giza, Egypt, 2000; pp. 542-556.

18. Pandey, J., Shubhashish, K and Pandey, R. (2010). Heavy metal contamination of Ganga river at Varanasi in relation to atmospheric deposition. Tropical Ecology, 51(2):365-373.

19. Oyeku, O.T and Eludoyin, A.O. (2010). Heavy metal contamination of ground water resources in a Nigerian urban settlement. African Journal of Environmental Science and Technology, 4(4):201214.

20. Rajappa, B., Manjappa, S. and Puttaiah, E.T. (2010). Monitoring of heavy metal concentration in groundwater of Hakinaka Taluk, India. Contemporary Engineering Sciences, 3(4):183190.
21. Jayana, B.L., Prasai, T., Singh, A. and Yami, K.D. (2009). Assessment of drinking water quality of madhyapur-thimi and study of antibiotic sensitivity against bacterial isolates. Nepal Journal of Science and Technology, 10:167-172.

22. W. J. S. Mwegoha and C. Kihampa (2010). Heavy metal contamination in agricultural soils and water in Dar es Salaam city, Tanzania. African Journal of Environmental Science and Technology Vol. 4(11), pp. 763-769.

23. Acharya, G.D., Hathi, M.V., Patel, A.D and Parmar, K.C. (2008). Chemical properties of groundwater in Bhiloda Taluka region, North Gujarat, India, E-Journal of Chemistry, 5(4), pp. 792-796,

24. Susan D. Richardson and Thomas A. Ternes (2005) Water Analysis: Emerging Contaminants and Current Issues, Analytical Chemistry. 77, 3807-3838.

25. Adewoye A.O, Opasola O.A and Elegbede J.A (2013) Physicochemical Parameters And Heavy Metal Analyses Of Water Samples From Hand Dug Wells In Gambari, Ogbomoso, Oyo State. IOSR Journal of Environmental Science, Toxicology and Food Technology5(1): pp 22-30. 